\title{
Lesson Study dalam Mata Kuliah Genetika Melalui Model Problem Based Learning pada Program Studi Pendidikan Biologi UNMAS Denpasar
}

\author{
Gusti Ayu Dewi Setiawati \\ Program Studi Pendidikan Biologi, Fakultas Keguruan dan Ilmu Pendidikan, \\ Universitas Mahasaraswati Denpasar, Bali \\ dewisetiawati@unmas.ac.id
}

\begin{abstract}
Abstrak
Lesson study merupakan suatu bentuk upaya pembinaan untuk meningkatkan proses pembelajaran yang dilakukan oleh sekelompok pengajar secara kolaboratif dan berkesinambungan dalam merencanakan, melaksanakan, mengobservasi, dan melaporkan hasil pembelajaran. Lesson study dapat diterapkan pada berbagai jenjang pendidikan, dari dasar hingga perguruan tinggi. Pelaksanaan lesson study mendukung UU No. 14 Tahun 2005 tentang guru dan dosen untuk meningkatkan kompetensi-kompetensi, yaitu kompetensi pedagogik, profesional, kepribadian, dan sosial. Lesson study pada mata kuliah genetika dilaksanakan pada semester gasal 2017/2018, di mana tahap pembelajaran yang dilakukan meliputi; perencanaan pembelajaran (plan), pelaksanaan pembelajaran $(d o)$, dan refleksi (see). Pelaksanaannya juga terdiri dari tiga siklus, di antaranya; siklus 1 dengan topik perubahan jumlah kromosom, siklus 2 dengan topik analisis pedigri dan siklus 3 dengan topik perubahan struktur kromosom. Implementasi ketiga siklus tersebut melalui model problem based learning, sehingga menampilkan topik permasalahan yang sesuai dengan model pembelajaran tersebut, yaitu siklus 1 dengan mengangkat permasalahan Sindrom Down, siklus 2 dengan mengangkat permasalahan pewarisan sifat rambut gimbal, dan siklus 3 dengan mengangkat permasalahan Sindrom Cri-Du-Chat. Hasil lesson study menunjukkan adanya peningkatan kualitas pembelajaran pada mata kuliah genetika, yaitu meliputi; variasi metode pembelajaran, variasi media, interaksi komponen pembelajaran, serta evaluasi. Dengan implementasi lesson study, pengajar menjadi lebih terbuka menerima masukan agar pembelajaran menjadi lebih baik, karena sesungguhnya tidak ada pembelajaran yang sempurna. Implementasinya secara berkelanjutan akan dapat meningkatkan profesionalisme dosen pada pelaksanaan pembelajaran pada mata kuliah masing-masing sehingga nantinya akan berdampak pada peningkatan mutu pembelajaran di perguruan tinggi.
\end{abstract}

Kata kunci: lesson study, genetika, problem based learning

\section{Pendahuluan}

Tidak ada pembelajaran yang sempurna, apalagi jika pembelajaran tersebut terlaksana tanpa perencanaan dan juga analisis terhadap komponen pembelajaran. Walaupun pada hakikatnya memang tidak ada pembelajaran yang benar-benar sempurna, maka sebaiknya dilakukanlah suatu tindakan baik berupa inovasi atau perbaikan untuk dapat meningkatkan mutu pembelajaran tersebut. Terdapat suatu model pembinaan profesi yang bertujuan meningkatkan proses pembelajaran yang disebut lesson study.

Lesson study adalah model pembinaan profesi pendidikan melalui pengkajian pembelajaran secara kolaboratif dan berkesinambungan berlandaskan prinsip-prinsip kolegalitas dan mutual learning untuk membangun komunitas belajar (Thobroni, 2016). Mutual learning yaitu saling belajar sehingga tidak ada anggota yang sifatnya lebih dari yang lain, bahkan yang 
memiliki pengetahuan lebih harus berbagi pada yang belum mengetahui. Lesson study berbeda dengan model pembelajaran serta metode pembelajaran, serta tidak dilakukan hanya sesaat namun berkesinambungan untuk memperbaiki proses dan hasil pembelajaran pebelajar. Lesson study mendukung UU. No. 14 Tahun 2005 tentang guru dan dosen untuk meningkatkan kompetensikompetensi pedagogik, profesional, kepribadian dan sosial.

Menurut Lewis (2002) dalam Depdiknas (2008) menyatakan bahwa lesson study mengandung makna yang sederhana, yaitu jika seorang guru ingin meningkatkan pembelajarannya, maka salah satu cara yang paling jelas adalah melakukan kolaborasi dengan guru lain untuk merancang, mengamati dan melakukan refleksi terhadap pembelajaran yang dilakukan. Sehingga dalam melaksanakan lesson study, kelompok guru atau dosen pada mata pelajaran tertentu bahu membahu bekerja untuk meningkatkan mutu pembelajarannya. Seorang dari anggota kelompok bertindak mengajar (guru/dosen model), sementara anggota lainnya mengamati. Pengamat tidak diperkenankan mengganggu/membantu pebelajar (siswa/mahasiswa) selama proses pembelajaran. Setelah kegiatan pembelajaran, pengajar dan pengamat melakukan sharing tentang aktivitas pebelajar. Pengamat sharing berdasarkan pembelajaran dan hasilnya digunakan untuk merevisi rencana pembelajaran (Thobroni, 2016).

Ciri-ciri penting dari lesson study adalah; (1) tujuannya bersifat jangka panjang, (2) lesson study difokuskan khusus untuk materi penting yang menjadi titik kelemahan siswa atau yang sulit dipelajari siswa, (3) fokus kegiatannya pada siswa (aktivitas, partisipasi, serta kondisinya) dalam pembelajaran, dan (4) observasi pembelajaran secara langsung (Lewis, 2009 dalam Thobroni, 2016). Pelatihan melalui lesson study bersifat bottom-up karena materi pelatihan berbasis permasalahan yang dihadapi para guru, kemudian dikaji secara kolaboratif dan berkelanjutan. Lesson study dapat diterapkan di setiap jenjang pendidikan, dari dasar hingga pendidikan tinggi. Depdiknas (2008) menambahkan tentang pentingnya lesson study diterapkan di perguruan tinggi, khususnya Lembaga Perguruan Tinggi Kependidikan (LPTK) yang mencetak guru karena lesson study dinilai sebagai cara yang efektif untuk meningkatkan mutu pembelajaran serta dapat menghasilkan guru/dosen yang inovatif.

Manfaat yang diperoleh dari pelaksanaan lesson study yaitu; (1) guru/dosen dapat mendokumentasikan kemajuan kerjanya, (2) dapat memperoleh umpan balik dari anggota lainnya, (3) dapat mempublikasikan dan mendiseminasikan hasil akhir lesson study. Sedangkan. tujuan pelaksanaannya adalah untuk; (1) meningkatkan pengetahuan terkait materi ajar, pembelajaran, motivasi untuk selalu berkembang, kualitas rencana pembelajaran, dan kemampuan guru/dosen dalam mengobservasi siswanya, (2) menguatkan hubungan antara pembelajaran sehari-hari dan tujuan jangka panjang (Thobroni, 2016). 
Sebagai suatu model pembinaan atau pelatihan, lesson study memiliki tahap-tahap yaitu; perencanaan (plan), pelaksanaan (do) dan refleksi (see). Tahap plan, dilakukan identifikasi masalah yang ada di kelas yang akan digunakan untuk kegiatan lesson study dan perencanaan alternatif pemecahannya. Identifikasi masalah dalam rangka perencanaan pemecahan masalah tersebut berkaitan dengan materi yang relevan kelas, karakteristik mahasiswa, metode/pendekatan pembelajaran, media, alat peraga, dan evaluasi proses dan hasil belajar.

Pada tahap do, dosen model melakukan implementasi rencana pelaksanaan perkuliahan (RPP) yang telah disusun tersebut, di kelas. Pakar dan dosen lain melakukan observasi dengan menggunakan lembar observasi yang telah dipersiapkan dan perangkat lain yang diperlukan. Para observer mencatat hal-hal positif dan negatif dalam proses pembelajaran, terutama tingkah laku mahasiswa. Selain itu (jika memungkinkan), dilakukan rekaman video (audio visual) yang mengclose-up kejadian-kejadian khusus (pada dosen atau mahasiswa) selama kegiatan pembelajaran. Hasil rekaman ini berguna nantinya sebagai bukti autentik kejadian-kejadian yang perlu didiskusikan dalam tahap refleksi atau pada seminar hasil lesson study, selain itu dapat digunakan sebagai bahan diseminasi.

Setelah melaksanakan praktik pembelajaran, maka refleksi (see) harus segera dilakukan. Pada tahap refleksi ini, dosen yang tampil dan para observer mengadakan diskusi tentang pembelajaran yang baru saja dilakukan. Diskusi ini dipimpin oleh Ketua Program Studi, dosen model dan observer lainnya yang ditunjuk oleh kelompok. Pertama, dosen model diberi kesempatan untuk menyatakan kesan-kesannya selama melaksanakan pembelajaran. Selanjutnya observer (dosen lainnya) menyampaikan hasil analisis data observasinya, terutama yang menyangkut kegiatan mahasiswa selama berlangsung pembelajaran yang disertai dengan pemutaran video hasil rekaman pembelajaran. Selanjutnya, dosen model memberikan tanggapan balik atas komentar para observer. Hal yang penting pula dalam tahap refleksi ini adalah mempertimbangkan kembali rencana pembelajaran yang telah disusun sebagai dasar untuk perbaikan rencana pembelajaran berikutnya.

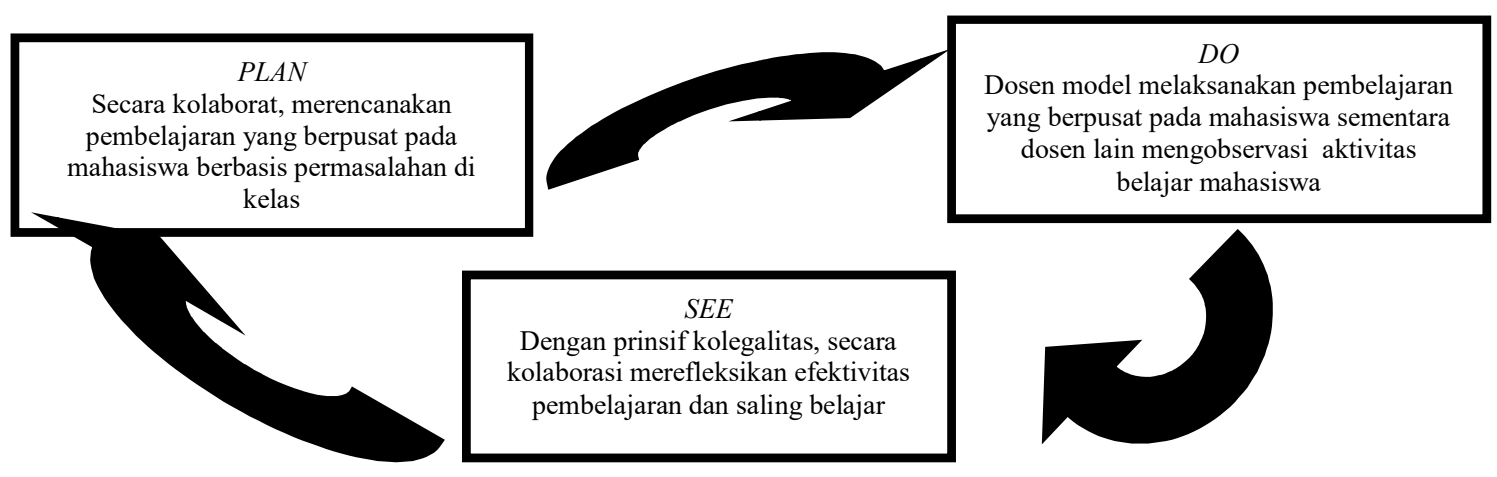

Gambar 1. Siklus kajian pembelajaran dalam lesson study

(Sumber: Dimodifikasi dari Depdiknas, 2008). 
Demikian pemaparan lesson study dari segi pengertian, ciri, manfaat, tujuan dan tahapannya, sehingga cocok diterapkan dalam meningkatkan mutu akademik pada Fakultas Keguruan dan Ilmu Pendidikan Universitas Mahasaraswati (Unmas) Denpasar.

Salah satu mata kuliah yaitu genetika merupakan mata kuliah wajib yang harus ditempuh oleh mahasiswa pada jenjang pendidikan Strata 1 (S1) pada Program Studi Pendidikan Biologi Unmas Denpasar. Mata kuliah ini mengkaji tentang pewarisan sifat pada makhluk hidup. Genetika merupakan salah satu materi dalam biologi yang sulit dipahami oleh peserta didik (Hera, 2017). Chu (2015) pun menyatakan bahwa materi genetika terasa sulit dimengerti oleh peserta didik karena materinya yang kompleks serta memerlukan banyak logika untuk mempelajarinya. Konsep-konsep genetika bersifat abstrak yang tidak dapat dipraktekkan secara langsung, kecuali melalui alat peraga, gambar atau video. Pembelajaran genetika di kelas cenderung berlangsung secara textbook oriented. Suratsih, dkk. (2009) terkait dengan hal tersebut juga menyatakan, pembelajaran genetika kurang memanfaatkan lingkungan sekitar peserta didik sebagai sumber belajar. Ilustrasi kasus yang digunakan biasanya diambil dari luar negeri karena sebagian besar sumber belajar merupakan hasil terjemahan (saduran) dari buku luar negeri. Selain itu, materi dan metode pembelajaran juga tidak divariasikan dalam pembelajaran genetika. Hal tersebut disebabkan kurangnya pengkajian dosen pengampu terhadap topik-topik materi lokal yang berada di sekitar untuk menciptakan pembelajaran yang lebih kontekstual. Dengan adanya penyampaian materi secara textbook oriented, tidak kontekstual dan metode pembelajaran yang monoton berdampak pada kurangnya interaksi mahasiswa dalam pembelajaran. Di setiap pembelajaran, mahasiswa yang bertanya maupun menjawab hanya berkisar satu hingga dua atau tiga orang mahasiswa. Sehingga, dosen pengampu nyaris menganggap mahasiswa cukup menguasai materi genetika tersebut. Namun setelah diadakan evaluasi, ternyata sebagian besar mahasiswa memperoleh nilai yang tidak memuaskan.

Dosen perlu mengadakan perubahan dalam pembelajarannya untuk peningkatan interaksi mahasiswa. Evaluasi yang hanya melalui nilai tugas, ujian tengah semester dan nila ujian akhir semester juga tidak refresentatif untuk menilai mahasiswa, sehingga perlu disesuikan dengan metode dan evaluasinya. Begitu kompleksnya permasalahan yang dihadapi dalam mata kuliah genetika, sehingga perlu dilakukan pembinaan pembelajarannya melalui lesson study.

Berdasarkan pemaparan tersebut, tujuan menerapkan lesson study dalam mata kuliah genetika yaitu agar; (1) materi genetika dapat dikaji dengan baik agar nantinya dapat disampaikan secara lebih kontekstual, sehingga mudah dipahami, (2) metode pembelajaran yang diterapkan lebih bervariasi untuk meningkatkan partisipasi dalam pembelajaran, (3) evaluasi pembelajaran yang diterapkan bersifat lebih otentik menggambarkan kemampuan mahasiswa, serta (4) interaksi 
dalam pembelajaran, baik antar mahasiswa maupun mahasiswa dengan dosennya mengalami peningkatan.

\section{Pembahasan}

Lesson study pada Program Studi Pendidikan Biologi Unmas Denpasar dilaksanakan pada semester gasal tahun akademik 2017/2018. Berdasarkan kesepakatan tim lesson study, model pembelajaran yang digunakan adalah problem based learning (PBL). Semester yang digunakan sebagai subyek lesson study adalah semester III (Tiga) dan V (Lima). Khusus untuk mata kuliah genetika digunakan semester $\mathrm{V}$ dengan jumlah mahasiswa sebanyak 30 orang. Kegiatan lesson study telah dilaksanakan dalam tiga siklus. Adapun setiap siklus melewati ketiga tahapan lesson study, yaitu plan, do, dan see.

\subsection{Tahap Plan}

Mata kuliah genetika merupakan mata kuliah dengan bobot 2 sks, maka dari itu durasi waktu pertemuan menjadi 2 x 50 menit. Tahap awal yang dilakukan adalah memilih tiga materi dengan karakter yang cukup sulit serta dapat dicari permasalahan yang sesuai dengan model PBL. Masalah dalam model PBL bersifat tidak terstruktur dan dapat dikaji secara multidisipliner (dari bidang ilmu yang berbeda) sehingga materi yang sesuai adalah materi yang dekat dengan keseharian mahasiswa atau kontekstual dengan tujuan agar mahasiswa dapat mengkajinya secara mendalam yang memungkinkan pengkajian secara multidisipliner. Kemudian dipilihlah tiga materi dengan inti yaitu kromosom yang terdiri dari, (1) perubahan jumlah kromosom, (2) analisis pedigri, dan (3) perubahan struktur kromosom. Untuk materi perubahan jumlah kromosom digunakan permasalahan Sindrom Down, materi analisis pedigri digunakan permasalahan sifat rambut gimbal dan materi perubahan struktu kromosom digunakan permasalahan Sindrom CriDu-Chat. Pertimbangan lain dari pemilihan masalah tersebut adalah; topik tersebut sifatnya terkini, isinya kompleks, isinya berpengaruh terhadap materi lainnya dan merupakan hasil diskusi dengan rekan dosen. Dosen model kemudian merancang chapter design, lesson design, Rencana Pelaksanaan Perkuliahan (RPP) serta Lembar Kegiatan Mahasiswa (LKM). Hal yang juga penting dalam tahap ini adalah pembentukan kelompok heterogen untuk memungkinkan mahasiswa belajar optimal dalam kelompoknya. Kelompok mahasiswa juga didiskusikan dalam tahap ini. Berdasarkan tahap plan, diperoleh masukan perbaikan sebagai berikut; (1) dosen model disarankan menggunakan media berupa video atau wacana untuk menampilkan permasalahan, (2) pemaparan materi pada RPP dipadatkan agar tidak terlampau banyak halaman RPP tersebut, (3) dosen model perlu menyiapkan rubrik penilaian autentik berupa penilaian presentasi karena pada sintaks terdapat kegiatan presentasi mahasiswa.

\subsection{Tahap Do}


Tahap pelaksanaan mengikuti RPP yang telah disusun di tahap sebelumnya. Pada siklus 1, materi yang dibawakan adalah perubahan jumlah kromosom dengan menampilkan masalah Sindrom Down melalui media video dan wacana. Metode yang digunakan ceramah, diskusi, tanya jawab, dan presentasi. Di siklus ini dosen model tidak melaksanakan pembelajaran sesuai dengan RPP, karena ternyata belum menyampaikan tujuan pembelajaran dan orientasi terhadap model PBL sehingga hanya beberapa mahasiswa yang fokus, sementara yang lainnya terlihat kebingungan. Sehingga interaksi mahasiswa juga terlihat kurang optimal.

Pada siklus 2, materi yang dibawakan adalah analisis pedigri dengan menampilkan masalah sifat rambut gimbal melalui media video tentang kehidupan orang-orang berambut gimbal di Dataran Tinggi Dieng dan peta silsilah keluarga rambut gimbal. Metode yang digunakan juga ceramah, diskusi, tanya jawab, dan presentasi. Pada siklus ini, dosen model menyampaikan tujuan pembelajaran dan juga orientasi terhadap PBL sehingga mahasiswa lebih terfokus mempelajari materi. Walaupun interaksi mahasiswa cukup optimal, namun dalam kelompok terdeteksi mahasiswa yang tidak aktif (mengandalkan temannya dalam mencari solusi).

Pada siklus 3, materi yang dibawakan adalah perubahan struktur kromosom dengan menampilkan permasalahan Sindrom Cri-Du-Chat melalui media wacana. Metode yang digunakan adalah ceramah, diskusi, tanya jawab, dan presentasi. Di siklus ini, dosen model telah memperbaiki pembelajaran sesuai refleksinya, kemungkinan sejalan dengan mahasiswa yang semakin familiar dengan model PBL pada siklus sebelumnya (siklus 1 dan 2), mahasiswa terlihat lebih terfokus sehingga interaksi terjadi secara optimal. Hal ini dapat diamati melalui peningkatan jumlah mahasiswa yang bertanya dan berbalas komentar terkait solusi permasalahan yang dikaji. Mahasiswa juga aktif menuliskan ke depan ide-idenya yang menandakan mahasiswa aktif dalam pembelajaran. Mengenai kurang aktifnya mahasiswa dalam kelompok telah diperbaiki oleh dosen model dengan cara lebih intensif ke kelompok-kelompok dalam mengarahkan diskusi mahasiswa di dalam kelompoknya.

\subsection{Tahap See}

Setelah tahap do, segera dilakukan tahap berikutnya yaitu tahap refleksi (see). Berdasarkan hasil monitoring refleksi, maka diperoleh temuan-temuan yang secara singkat diungkap sebagai berikut. Pada siklus 1, dosen model mengakui kekurangannya yaitu tidak menyampaikan tujuan pembelajaran serta orientasi model PBL sebelum menyampaikan materi. Selain itu, dosen model mengaku merasa grogi karena tampil sebagai dosen model lesson study merupakan hal yang baru bagi yang bersangkutan. Jika dipersentasekan sebanyak 75\% komentar yang diberikan oleh observer bersifat membangun bagi dosen model. Namun ternyata, dosen model dan observer belum terlalu fokus membahas aktivitas mahasiswa. Hal yang bisa ditiru dari 
dosen model adalah dosen bersemangat dalam menyajikan materi dan antusias dalam mengelola pembelajaran di kelas.

Pada siklus 2, dosen model mengakui telah memperbaiki kekurangannya pada siklus 1 sehingga mahasiswa menjadi lebih terfokus belajar. Observer juga memberikan 85\% komentar yang membangun. Komentar yang diberikan sudah mulai lebih terfokus pada aktivitas mahasiswa, bukan membahas kekurangan dosen model semata. Mahasiswa kini menempati porsi utama dibahas dalam tahap refleksi. Jika pada siklus 1 , sintaks presentasi dibawakan dengan lisan oleh mahasiswa, pada siklus 2 sudah terjadi peningkatan yaitu dibawakan dengan lisan dan tertulis di papan tulis.

Pada siklus 3, dosen model mengakui telah memperbaiki kekurangannya pada siklus 1 dan 2, sehingga mahasiswa tetap terfokus belajar seperti pada siklus 2 dan bahkan lebih menampakkan peningkatan karena terjadi interaksi berupa tanya jawab yang pada siklus sebelumnya belum terlalu tampak. Kemungkinan hal ini dipengaruhi oleh mulai terbiasanya mahasiswa menghadapi model pembelajaran PBL dan lesson study, mengingat ini merupakan siklus 3. Pada siklus 3 ini, mahasiswa terlihat menikmati pembelajaran dan terlihat bebas dalam menyalurkan pendapatnya melalui presentasi hasil investigasinya. Komentar observer sudah terfokus pada tingkah laku mahasiswa baik secara individu maupun dalam kelompoknya. Tercatat komentar yang membangun sekitar $85 \%$. Hal yang bisa ditiru tetap pula dipertahankan yaitu bersemangat dalam mengelola pembelajaran, dan antusias dalam mengelola kelas. Karakter dosen model sangat terlihat pada siklus 1, 2 maupun 3 di mana dosen perhatian pada mahasiswa, hal ini dapat diamati dari dosen model yang hafal dengan nama mahasiswanya. Interaksi dalam siklus 3 juga terlihat mengalami peningkatan dari siklus sebelumnya, yang kemungkinan disebabkan karena mahasiswa mulai terbiasa dengan model PBL dan lesson study serta kedekatannya dengan dosen yang telah menemani mahasiswa belajar dan berdiskusi masalah-masalah yang juga telah dipelajari sebelumnya pada siklus 1 dan 2 .

Penerapan lesson study dalam mata kuliah genetika menunjukkan terjadinya peningkatan kualitas pembelajaran, terutama dari segi proses dan hasilnya. Dengan pelaksanaannya, diperoleh manfaat lesson study terutama pada lembaga pencetak tenaga guru seperti yang dinyatakan Depdiknas (2008) yaitu; (1) mengurangi keterasingan dosen dan komunitasnya dalam perencanaan dan pelaksanaan pembelajaran dan perbaikannnya, (2) membantu pendidik unntuk mengobservasi dan mengkritisi pembalajaran, (3) memperdalam pemahaman pendidik tentang materi pelajaran, cakupan dan urutan kurikulum, (4) membantu pendidik memfokuskan batuannya pada seluruh aktivitas belajar mahasiswa, (5) meningkatkan akuntabilitas kinerja dosen, (6) menciptakan terjadinya pertukaran pemahaman tentang cara berpikir dan belajar mahasiswa, (7) meningkatkan kolaborasi pada sesama pendidik dalam pembelajaran, (8) 
meningkatkan mutu pendidik dan mutu pembelajaran yang pada gilirannya berakibat pada peningkatan mutu lulusan (mahasiswa), (9) pendidik memiliki banyak kesempatan untuk membuat bermakna ide-ide pendidikan dalam praktik pembelajaran dan belajar praktik pembelajaran dari perspektif mahasiswa, (10) perbaikan praktik pembelajaran di kelas, dan (11) peningkatan keterampilan menulis karya tulis ilmiah atau buku ajar.

\section{Penutup}

\section{Simpulan}

Berdasarkan hasil penelitian maka diperoleh simpulan sebagai berikut.

1) Lesson study pada mata kuliah genetika pada Prodi Pendidikan Biologi Universitas Mahasaraswati Denpasar dilaksanakan pada semester gasal tahun akademik 2017/2018 dengan menggunakan model pembelajaran problem based learning (PBL).

2) Lesson study pada mata kuliah genetika dilakukan sebanyak tiga kali siklus dengan tiga topik atau masalah, yaitu; (1) perubahan jumlah kromosom dengan mengkaji masalah sindrom Down, (2) analisis pedigri dengan mengkaji pewarisan sifat rambut gimbal, dan (3) perubahan struktur kromosom dengan mengkaji masalah sindrom Cri-Du-Chat.

3) Hasil pembelajaran genetika dengan pembinaan lesson study melalui model PBL menunjukkan bahwa terjadi peningkatan kualitas dari segi penyampaian materi sudah menggunakan media yang beragam hal ini otomatis dapat terjadi karena penggunaan model PBL sehingga media dan model menjadi bervariasi. Selain itu, peningkatan mutu juga terjadi dari segi metode yang bervariasi, evaluasi yaitu telah menggunakan rubrik sikap, keterampilan berkelompok hingga rubrik penilaian autentik yaitu presentasi yang sudah beragam dan juga interaksi yang teramati dalam pembelajaran.

\section{Saran}

Saran yang dapat disampaikan terkait pelaksanaan lesson study adalah sebagai berikut.

1) Dengan mempertimbangkan peningkatan kualitas pembelajaran yang dapat dicapai melalui implementasinya, maka lesson study perlu diterapkan lagi pada maka kuliah lainnya.

2) Perlu dipertahankan jika dosen observer tidak hanya dari team teaching tetapi berasal dari dosen serumpun agar masukan terhadap pembelajaran menjadi lebih kompleks.

3) Perlu dilakukan diseminasi hasil pelaksanaan lesson study agar memungkinkan terjadi diskusi dan bertukar pengalaman dalam mengelola pembelajaran.

\section{Ucapan Terima Kasih}

Om Suastyastu, 
Puji syukur saya panjatkan kehadapan Ida Sang Hyang Widhi Wasa, Tuhan Yang Maha Esa karena berkat rahmat-Nya, makalah seminar lesson study ini berhasil disusun. Melalui kesempatan ini pula, saya mengucapkan terima kasih yang sedalam-dalamnya pada rekan-rekan dosen Program Studi Pendidikan Biologi Unmas Denpasar baik rekan team teaching maupun serumpun atas motivasinya dalam pelaksanaan penelitian dan penulisan makalah ini. Serta tidak lupa pula saya ucapkan terima kasih atas motivasi, bantuan, dan doa dari keluarga. Semoga semua diberikan berkah dan limpahan karunianya dan semoga pula makalah ini bermanfaat.

Om Shanti, Shanti, Shanti Om.

\section{Daftar Pustaka}

Arsy, D. K. W. S., Istamar Syamsuri, Balqis. (2011). Kajian implementasi lesson study pada pengembangan pembelajaran IPA berbasis inkuiri dan PBL kelas VII SMP untuk meningkatkan motivasi belajar, hasil belajar peserta didik dan keprofesionalan guru. Terdapat pada http://jurnalonline.um.ac.id/data/artikel/artikelA02E1394D12535FA1BBAA25BF688BB73.pdf, diakses tanggal 11 Desember 2017.

Chu, Villing. (2015). Pembuatan aplikasi pembelajaran genetika bagi siswa SMP Kelas IX. Jurnal Ilmiah Mahasiswa Universitas Surabaya. Volume 4 Nomor 1 Tahun 2015.

Departemen Pendidikan Nasional. (2008). Program perluasan lesson study untuk penguatan LPTK. Terdapat pada https://acenale.files.wordpress.com/2011/04/, diakses tanggal 11 Desember 2017.

Hera, Rufa. (2017). Studi kasus permasalahan dalam proses pembelajaran konsep genetika di SMA Negeri 2 Seulimum Kabupaten Aceh Besar. Jurnal Genta Mulia, Volume VIII No. 1, Januari 2017.

Menuju guru yang profesional melalui lesson study. Terdapat pada https://educatinalwithptkdotnet.files.wordpress.com/2013/01/19-menuju-guru-yangprofesional-melalui-lesson-study.pdf, diakses tanggal 11 Desember 2017.

Rakhmawati, Anna, Bernadetta Octavia, Siti Umniyatie. (2010). Implementasi lesson study dalam mata kuliah mikrobiologi Jurdik Biologi FMIPA UNY. Terdapat pada http://staff.uny.ac.id/sites/default/files/131268116/, diakses tanggal 11 Desember 2017.

Suryo. (2011). Genetika manusia. Yogyakarta: Gadjah Mada University Press.

Thobroni, M. (2016). Belajar dan pembelajaran: teori dan praktik. Yogyakarta: Ar-Ruz Media. 